\title{
Proteomics Informed by Transcriptomics for a Qualitative and Quantitative Analysis of the Sialoproteome of Ornithodoros Moubata Adult Ticks
}

\author{
Ana Oleaga ( $\square$ ana.oleaga@irnasa.csic.es ) \\ IRNASA, CSIC \\ Angel Carnero-Moran \\ IRNASA: Instituto de Recursos Naturales y Agrobiologia de Salamanca \\ M. Luz Valero \\ University of Valencia: Universitat de Valencia \\ Ricardo Pérez-Sánchez \\ IRNASA: Instituto de Recursos Naturales y Agrobiologia de Salamanca
}

\section{Research Article}

Keywords: Ornithodoros moubata, saliva, proteome, LC-MS/MS, SWATH-MS.

Posted Date: May 17th, 2021

DOI: https://doi.org/10.21203/rs.3.rs-512926/v1

License: @ (i) This work is licensed under a Creative Commons Attribution 4.0 International License. Read Full License

Version of Record: A version of this preprint was published at Parasites \& Vectors on August 11th, 2021. See the published version at https://doi.org/10.1186/s13071-021-04892-2. 


\section{Abstract \\ Background}

The argasid tick Ornithodoros moubata is the main vector in mainland Africa of the African swine fever virus and the spirochete Borrelia duttoni, which causes human relapsing fever. Elimination of $O$. moubata populations would contribute to the prevention and control of these two severe diseases. The development of anti-tick vaccines is an eco-friendly and sustainable method for the elimination of tick populations. The tick saliva forms part of the tick-host interface and knowing its composition is key for the identification and selection of vaccine candidate antigens. The aim of the present work is to expand the data on the saliva proteome composition of 0 . moubata adult ticks, particularly of female ticks, since a more in-depth knowledge of the 0 . moubata sialome will allow identifying and selecting novel salivary antigens as targets for tick vaccines.

\section{Methods}

We have analysed samples of female and male saliva using two different mass spectrometry approaches: data-dependent acquisition LC-MS/MS and sequential window acquisition of all theoretical fragment ion spectra mass spectrometry (SWATH-MS). To maximise the number of protein identifications, a proteomics informed by transcriptomics (PIT) analysis was applied using the 0 . moubata salivary transcriptomic dataset previously obtained by RNAseq.

\section{Results}

The SWATH-MS proved to be superior to LC-MS/MS in the study of female saliva since it increased by $60 \%$ the number of identified proteins, enhanced the reproducibility of the results and provided a quantitative image of the saliva components. As a whole, we have identified 299 non-redundant proteins in the 0 . moubata saliva and quantified the expression of 165 of them in both male and female saliva, among which 13 were significantly overexpressed in females and 40 in males. These results evidence important quantitative differences between sexes in the saliva proteome.

\section{Conclusions}

This work expand our knowledge of the 0 . moubata sialome, particularly of female ticks, by increasing the identification of novel salivary proteins and functions at the tick-host feeding interface. The integration of this new knowledge together with the information from the 0 . moubata sialotranscriptome will allow a more rational selection of the salivary candidates as antigen targets for tick vaccine development.

\section{Background}

Ticks are important blood-sucking arthropods in human and veterinary medicine due to their capacity to transmit a wide variety of infectious agents including viruses, bacteria and protozoans, which can cause severe diseases to people and pets as well as domestic and wild animals [1,2].

Ornithodoros moubata is an argasid tick broadly distributed in numerous countries of eastern, central and southern mainland Africa and Madagascar. This tick lives in sylvatic environments associated mainly with warthogs and other animals inhabiting burrows, but it also invades synanthropic environments and colonises human dwellings and domestic animal premises, particularly pig premises [3]. In these countries, $O$. moubata has a significant medical and veterinary impact due to its function as a vector for Borrellia duttoni, a spirochete that causes tick-borne human relapsing fever 
(TBRF), and for the African swine fever (ASF) virus. The TBRF caused by $B$. duttoni is endemic in extensive zones of east Africa, affecting up to $6.4 \%$ of the population and causing perinatal mortality rates as high as 436 per $1000[4,5]$. ASF is an acute febrile haemorrhagic disease of swine, with lethality rates close to $100 \%$, which limits pig production and causes enormous economic losses in affected countries $[6,7]$.

In this context, elimination of domestic and peridomestic 0 . moubata populations would positively affect the prevention and control of these two severe diseases. The main strategy of tick control still is the application of chemical acaricides, despite their use having serious drawbacks such as the selection of tick resistant strains and toxicity as well as environmental and animal product contamination $[8,9]$. In addition, chemical agents are ineffective for eliminating $O$. moubata from inside human dwellings and animal pens simply because they do not penetrate enough to reach the ticks in all the holes, cracks and fissures where they can take refuge, as was observed in Spain with Ornithodoros erraticus [10].

The development of anti-tick vaccines has proved to be an alternative eco-friendly and sustainable method for tick control with clear advantages over the application of chemical agents [11]. With that aim, years ago our team initiated the development of a vaccine for the control of 0 . moubata and focused our interest on the parasite antigens that are part of the tick-host interface and participate in the tick-host interplay, namely the salivary and intestinal tick antigens [12].

In the last decade, omics technologies such as next-generation sequencing (NGS) and high-throughput proteome analysis have been used to explore the sialomes and mialomes of several hard and soft tick species [13-15]. These studies have resulted in the identification of a range of tick molecules involved in the molecular mechanisms beneath tick haematophagy, tick-host interactions and pathogen transmission [13].

In 0 . moubata, we have recently applied omics technologies to analyse and characterise the transcriptome and proteome of the female tick midgut (mialome) before and after tick feeding $[16,17]$. The obtained omics datasets have allowed us the selection of several vaccine candidate antigens, which were produced as recombinant proteins or as synthetic peptides and tested for vaccine efficacy in animal immunisation trials. Some of these candidates proved protective against Ornithodoros spp. and thus potentially useful to be included in vaccine formulations for tick control [18].

Regarding 0 . moubata salivary antigens, we have recently tackled their characterisation in depth by obtaining and analysing the female salivary transcriptome throughout the trophogonic cycle [19]. The newly obtained data have significantly increased the repertory of argasid salivary protein-coding sequences available in public databases and its analysis will facilitate the identification of new antigen candidates for the development of tick vaccines. Moreover, this annotated sialotranscriptome constitutes an invaluable reference database for future studies on the 0 . moubata salivary proteome, and it may be useful to confirm and expand former data on the salivary proteome of 0 . moubata, which were obtained in two former studies $[20,21]$. These studies are the only ones on the 0 . moubata sialoproteome performed until now, and their results in terms of protein identification were limited by the scarcity of known tick sequences available at the time when these studies were executed.

The study by Oleaga et al. [20] analysed the proteome of the salivary glands of females by two-dimensional SDS-PAGE and MALDI-TOF MS, while the study by Diaz-Martín et al. [21] used LC-MS/MS to study the proteome of the female and male saliva separately.

Diaz-Martín et al. [21] observed noteworthy differences in the proteome composition between the sexes, as well as a high overrepresentation of some lipocalin proteins in female saliva, which hindered the identification of the most of the female saliva proteome, constituted by much less abundant proteins. Although equalising the saliva samples significantly increased the number of identified proteins, this treatment precluded the quantification of each protein component in the native saliva samples [22]. 
The specific aim of the present work is to expand the data on the salivary proteome of 0 . moubata adult ticks, particularly of female ticks, by solving the aforementioned drawbacks, as part of the in-depth characterisation and analysis of the $O$. moubata sialome. Knowing this sialome will allow identifying and selecting novel salivary antigens as targets for tick vaccines, and their subsequent testing in animal immunisation trials. We pay special attention to female ticks because they are a key developmental stage in the tick life cycle and vaccines may exert on them double deleterious effects, for instance, an increase in mortality and a reduction/inhibition of reproductive performance.

With that aim, in the current work, we have analysed samples of female and male saliva separately using two different mass spectrometry approaches: data-dependent acquisition (DDA) LC-MS/MS and sequential window acquisition of all theoretical fragment ion spectra mass spectrometry (SWATH-MS). This last technique is a specific variant of dataindependent acquisition (DIA) methods and is an emergent technology that combines deep proteome coverage with quantitative consistency and precision [23].

To maximise the number of protein identifications, we have applied a proteomics informed by transcriptomics (PIT) analysis, which consisted of using the $O$. moubata salivary transcriptomic dataset previously obtained by RNAseq [19] as a reference database for protein identification.

Additionally, besides the analysis of the acquired proteomics data for protein identification and comparative quantification between female and male ticks, a comparative analysis of the performance and reproducibility between LC-MS/MS and SWATH-MS was done, which demonstrated greater usefulness and advantages of SWATH-MS over LC-MS/MS for the identification and quantification of the salivary proteins of 0 . moubata females.

\section{Material And Methods}

\section{Tick specimens}

The 0 . moubata specimens used in the present work come from the IRNASA colony, which was established from specimens donated by Dr Philip Wilkinson (Institute for Animal Health, Pirbright, United Kingdom) captured in Malawi.This colony is kept at $28^{\circ} \mathrm{C}, 85 \%$ relative humidity and $12 / 12$ hours of light/dark, and is regularly fed on rabbits.

\section{Tick saliva collection}

Saliva was collected separately from each sex from newly moulted 4-month-old female and male ticks after stimulation of secretion with pilocarpine following the protocol described by Baranda et al. [24] with the following modifications.

Tick specimens were sequentially washed by immersion and shaking inside a $50 \mathrm{ml}$ disposable centrifuge tube in the following series of $25-\mathrm{ml}$ solutions: tap water, $3 \%$ hydrogen peroxide, two washes in distilled water, $70 \%$ ethanol and two more washes in distilled water. After that, ticks were dried on paper towels and immobilised with double side adhesive tape on a glass plate. Each tick was administered $1 \mu \mathrm{l}$ of $1 \%$ pilocarpine hydrochloride (Sigma) in phosphate-buffered saline (PBS) $\mathrm{pH} 7.4$ through the genital pore using a $5 \mu$ Hamilton syringe, 33 gauge, $25 \mathrm{~mm}$ length needle. Shortly after stimulation, the tick started to move the chelicerae and emit small droplets of clear viscous saliva $(<0.5 \mu \mathrm{l})$, which were harvested from the tick mouthparts using a micropipette, and deposited on $150 \mu$ of ice-cooled PBS. Saliva was collected from the ticks while perceptible emission continued, usually during 30-40 min after stimulation.

Three replicated biological saliva samples from each sex were prepared, each containing the secretion of 20 female ticks/sample (F1, F2, F3) or 40 male ticks/sample (M1, M2, M3). Saliva samples were centrifuged $10 \mathrm{~min}$ at $12.000 \times \mathrm{g}$ and $4{ }^{\circ} \mathrm{C}$, and the supernatants were recovered and stored at $-20^{\circ} \mathrm{C}$. Protein concentration was assessed by measuring the 
absorbance at $280 \mathrm{~nm}$ in the NanoDrop 2000 spectrophotometer (ThermoFisher), and sample reproducibility was checked by SDS-PAGE (Additional file 1: Fig 1).

\section{Protein digestion and sample preparation}

Trypsin digestion and proteomic analyses were carried out at the SCSIE University of Valencia Proteomics Unit, a member of ISCIII ProteoRed Proteomics Platform.

Salivary proteins in each female (F1, F2, F3) and male (M1, M2, M3) saliva sample were analysed using an in-solution digestion method. For this, $20 \mu \mathrm{g}$ of protein per sample were digested with Sequencing Grade Trypsin (Promega) as follows. First, protein samples were reduced using $10 \mathrm{mM}$ dithiothreitol (DTT) (Sigma) to a final volume of $100 \mu \mathrm{l}$ and the mixture incubated for $20 \mathrm{~min}$ at $60^{\circ} \mathrm{C}$. Then, proteins were alkylated with $5.5 \mathrm{mM}$ iodoacetamide (IAM) (Sigma) to a final volume of $110 \mu \mathrm{l}$ and incubated at room temperature for $30 \mathrm{~min}$ in the dark. Finally, each sample was digested with 800 ng of trypsin in a final volume of $118 \mu \mathrm{l}$ and incubated overnight at $37^{\circ} \mathrm{C}$. The digestion was stopped with $12 \mu \mathrm{L}$ of $10 \%$ trifluoroacetic acid (TFA) (Fisher Scientific) in water. The mixtures were dried in a rotatory evaporator and dissolved in a final volume of $40 \mu \mathrm{l}$. All the reagents were prepared in $50 \mathrm{mM}$ ammonium bicarbonate (ABC) (Sigma).

\section{Liquid chromatography-tandem mass spectrometry (LC-MS/MS) analysis and building a spectral library}

The peptides recovered from the in-solution digestion processing were analysed in a microESI qQTOF mass spectrometer (6600plus TripleTOF, ABSCIEX) in a data-dependent acquisition (DDA) mode. Briefly, for LC-MS/MS analysis, $5 \mu$ from each digested sample ( 6 samples; 3 from females and 3 from males) were individually loaded using a nanoLC 425 (Eksigent) onto a trap column $(3 \mu \mathrm{C} 18-\mathrm{CL} 120 \AA$, $350 \mu \mathrm{m} \times 0.5 \mathrm{~mm}$; Eksigent) and desalted with $0.1 \%$ TFA at $5 \mu \mathrm{l} / \mathrm{min}$ for 5 $\mathrm{min}$. Then, the peptides were separated using an analytical LC column $(3 \mu \mathrm{C} 18-\mathrm{CL} 120 \AA \bar{A}, 0.075 \times 150 \mathrm{~mm}$; Eksigent) equilibrated in $5 \%$ acetonitrile (ACN) (Fisher Scientific) $0.1 \%$ formic acid (FA) (Fisher Scientific). Peptide elution was carried out with a linear gradient of $7-40 \%$ of buffer $B$ in A for 45 min (A: $0.1 \%$ FA in water; B: $0.1 \%$ FA in ACN) at a flow rate of $300 \mathrm{nl} / \mathrm{min}$. The eluted peptides were ionised in a source type Optiflow applying $3.0 \mathrm{kV}$ to the spray emitted, and the tripleTOF was operated in a data depending acquisition (DDA) mode. Full profile MS scans were acquired in the mass range of $\mathrm{m} / \mathrm{z} 350-1400$ for $250 \mathrm{~ms}$ in positive ion mode. The top 100 most intense ions were selected for fragmentation and MS/MS scans were acquired in the mass range of m/z 100-1500 for 25 ms in "high sensitivity" mode. Switch criteria used were the following: charge of $2+$ to $4+$, minimum intensity, and 100 counts per second. As is described below, the results of these analyses were used in a comparative analysis of the reproducibility and performance between LC-MS/MS in DDA mode and SWATH-MS.

For building a spectral library for SWATH-MS analysis, $2 \mu$ l of every digested sample were pooled and $5 \mu$ l of the pool were processed and analysed by LC-MS/MS exactly the same as described before for the individual samples. All the spectra obtained were combined and used for the generation of the reference spectral ion library as part of SWATH-MS analysis. The scheme of the workflow for spectral library creation as well as for sample processing is represented in Fig. 1.

\section{Sequential window acquisition of all theoretical fragment ion spectra (SWATH) mass spectrometry (MS) analysis}

SWATH-MS data for both female and male saliva samples were acquired on the same MS instrument used for LC-MS/MS. 
The liquid chromatography conditions were the following. Five $\mu \mathrm{l}$ of each digested sample were loaded onto a trap column (LC Column, $12 \mathrm{~nm}, 3 \mu$ Triart-C18, $0.5 \times 5.0 \mathrm{~mm}$; YMC) and desalted with $0.1 \%$ TFA at $10 \mu \mathrm{l} / \mathrm{min}$ for $5 \mathrm{~min}$. The peptides were then loaded onto an analytical column (LC Column, Luna Omega $3 \mu \mathrm{m}$ Polar C18, $150 \times 0.3 \mathrm{~mm}$, Capillary Phenomenex) equilibrated in 3\% ACN 0.1\% FA. Peptide elution was performed with a linear gradient of 3-35\% B in A for 45 $\min (\mathrm{A}: 0.1 \% \mathrm{FA} ; \mathrm{B}: \mathrm{ACN}, 0.1 \% \mathrm{FA})$ at a flow rate of $300 \mathrm{nl} / \mathrm{min}$.

The samples were acquired in a random order to avoid bias in the analysis. Sample was ionized in a source type Optiflow 1-50 $\mu \mathrm{L}$ micro, applying $4.5 \mathrm{kV}$ to the spray emitter and the analysis was carried out in a data-independent acquisition (DIA) mode. Survey MS1 scans were acquired from 400-1250 m/z for $250 \mathrm{~ms}$ and 100 variable windows from 400 to $1250 \mathrm{~m} / \mathrm{z}$ were acquired throughout the experiment. The total cycle time was $2.79 \mathrm{secs}$. The quadrupole resolution was set to 'UNIT' for MS2 experiments, which were acquired from 100-1500 m/z for 25 ms in 'high sensitivity' mode.

\section{Identification and quantification of proteins}

After LC-MS/MS, the wiff data files were processed using ProteinPilot v5.0 search engine (AB SCIEX). The Paragon algorithm [25] of ProteinPilot was used to search against a recently published protein fasta database derived from the $O$. moubata sialotranscriptome [19], (BioProject PRJNA667315). Searches were done with trypsin specificity, cys-alkylation and the search effort set to rapid.

To avoid using the same spectral evidence in more than one protein, the identified proteins were grouped based on MS/MS spectra by the Protein-Pilot Pro Group ${ }^{\mathrm{TM}}$ Algorithm, regardless of the peptide sequence assigned. The protein within each group that could explain more spectral data with confidence was depicted as the primary protein of the group.

Among the proteins identified by LC-MS/MS in DDA mode in each saliva sample, only those showing a Protein Pilot unused score above 1.3 (> 95\% confidence) and a False Discovery Rate (FDR) lower than 1\% were considered significant and included in the ensuing analyses. After manually inspecting all the proteins identified by LC-MS/MS, redundant identifications were removed by selecting the proteins with the highest score, and the hits of non-annotated transcripts were removed as well.

The identified proteins by SWATH-MS were quantified using PeakView 2.2 software from normalised label-free quantification intensity data. The generated spectral library was used as a database in Peak View 2.2 software for SWATH analysis and peaks from SWATH runs were extracted with a peptide confidence threshold of $95 \%$ and FDR lower than $1 \%$. It was not set up to a minimum number of peptides for the identification. Quantitated proteins areas were normalised by total areas sum for differential expression analysis. In case of redundant identifications, the hit with a higher p-value was selected as representative and the normalised area values of the redundant proteins were added and the fold change recalculated.

\section{Bioinformatic analyses}

For functional annotations of the proteins identified, Uniprot IDs of the proteins were used to extract the Gene Ontology (GO) terms for biological process, molecular function, cellular component as well as cross-references in the InterPro, Pfam and Panther databases. The identified proteins were then functionally classified according to $\mathrm{GO}$ terms and bibliographic information, taking as a model the classification applied by Kim et al. [26] in their study of the proteome of Amblyomma americanum tick saliva.

\section{Statistical analysis}


The quantitative data obtained by PeakView were analysed using MarkerView (v1.2, AB SCIEX). First, areas were normalised by total areas sum. Multiexperiment Viewer (MeV) (http://www.tm4.org/mev.html) was used to identify the protein differentially expressed in saliva between female and male ticks using Welch's t-test subjected to Bonferroni correction. Salivary proteins showing an adjusted $p$-value $\leq 0.05$ were considered significantly differentially expressed between female and male ticks. The mean quantity of proteins in each saliva sample and the fold-change (ratio between the mean of proteins of female versus proteins of male) were calculated. The results of the hierarchical clustering analysis of the differentially expressed proteome profile of female and male samples were shown using a heat map after z-score normalisation using Euclidean distances.

\section{Results And Discussion Spectral library}

Spectral libraries are essential for effective post-acquisition processing of SWATH data because they contain spectrometric data for all peptide precursors and their respective ion fragments, which are extracted from prior DDA MS experiments [27].

In the current work, we have generated a spectral library for 0 . moubata saliva proteins from DDA MS experiments involving 3 female and 3 male saliva samples. Additional file 2: Table S1 is the Protein Pilot report showing the spectrometric, statistic and identification data in the spectral library generated from 0 . moubata saliva proteins. This library included 5,497 spectra associated with $99 \%$ confidence, corresponding to 3,734 distinct peptides and 388 protein sequences with a FDR $\leq 1 \%$. After eliminating, from the 388-protein list, up to 65 redundant identifications and 64 hits to non-annotated sequences from the 0 . moubata sialotranscriptome database, we obtained a final list of 259 non-redundant salivary proteins (Additional file 3: Table S2). This list includes all the proteins identified in the saliva of both sexes and was used as our reference library for the analysis of SWATH data.

Functional classification of these 259 proteins showed that the most numerous protein functional groups and families were the proteins involved in metabolic processes $(n=48)$, proteases $(n=28)$, antioxidants $(n=20)$, protease inhibitors $(n=$ $17)$, and proteins with unknown function $(n=36)$ (Table 1). Typically, these families and groups are also the most abundantly represented in the sialomes of the soft and hard tick species analysed to date [15].

\section{Results obtained by LC-MS/MS in DDA mode}

Besides generating the spectral library, we have analysed individually each sample of female and male saliva by LCMS/MS. For simplicity, the lists of protein identifications obtained in the analyses of the individual replicated samples were combined in two unique lists, one for each sex, which were later filtered by eliminating the redundancies and the nonannotated hits. Table 2 and Additional file 3: Table S2 show 195 and 64 proteins identified in male and female saliva, respectively. Of them, 36 proteins are shared by both sexes, and 159 and 28 are unique to males and females, respectively (Fig. 2).

The presence of some differences in protein composition between the saliva of 0 . moubata females and males can also be observed in the different protein band patterns shown by the saliva of each sex in SDS-PAGE (Additional file: Fig. S1), and it has already been described by Díaz-Martin et al. [21] who also confirmed the massive presence of lipocalin proteins in female saliva. The hyper-abundance of lipocalins would have hampered the detection of the less abundant proteins, which most likely would have remained below the detection limits of the assays. As proof of this was the fact that when the saliva samples were equalised and the "excess" of the hyperabundant proteins removed, the number of proteins identified in females increased very significantly [21, 28]. At that time, the work by Díaz-Martín et al. [21] provided 
interesting novel information on the saliva proteome of males and females and revealed for the first time for soft tick differences in the saliva composition between both sexes. However, this study had an inconvenient, the method applied to increase the number of identifications, namely, the protein equalisation with the ProteoMiner Kit (BioRad), precluded the quantification of its components.

In ixodid ticks, the observed differences between males and females in the saliva composition are not surprising since both the feeding behaviour and the anatomy and functions of the salivary glands of both sexes are different $[29,30]$. However, the differences reported between 0 . moubata males and females in the salivary composition were somewhat surprising since typically soft tick adults, and specifically 0 . moubata adults, do not show anatomical differences in their salivary glands and they feed similarly. They ingest equivalent amounts of blood relative to their body weight and do it for a similar time, about an hour. This means that both sexes are obliged to overcome the same barriers and host defensive responses to complete blood ingestion, so it would be expected that both sexes would use the same repertory of antidefensive salivary proteins [21].

In the current study, the different set of proteins identified by LC-MS/MS in female and male saliva also suggest qualitative differences in the salivary composition between sexes, following that was reported [21]. However, it must be noted that the reference database used in the present study for protein identification, i.e. the 0 . moubata sialotranscriptome, was obtained from female salivary glands only. Consequently, it might be assumed (i) that most likely the majority of the proteins identified in the present study, including those found in males only, would also be present in female saliva, and (ii) that the differences observed between sexes may be due more probably to quantitative differences in expression than to real absence/presence of particular proteins in one or another sex. As we will see later, the results of SWATH-MS also lend support to this idea.

Accordingly, it can be assumed that part of the qualitative differences observed by Diaz-Martin et al. [21] between the proteomes of male and female saliva, in which only $5.2 \%$ of the identified proteins were common, would possibly be due to quantitative differences.

\section{Comparing LC-MS/MS and SWATH-MS analyses}

To increase the number of protein identifications in both female and male saliva and quantify the protein expression level we analysed the saliva samples by two methods: LC-MS/MS operated in DDA mode and the free-label quantitative method SWATH-MS that operates in DIA mode.

Mass spectrometry methods that operate in DDA mode are based on the random selection and fragmentation of a fixed number of peptide precursors, generally the most intense peptide ions. On the other hand, in a SWATH-MS capture, all ionised peptides of a given sample that fall within a specified mass range are fragmented in a systematic and unbiased fashion using rather large precursor isolation windows [23]. Several published SWATH studies have demonstrated that SWATH-MS increases the sensitivity and the reproducibility of protein and peptide identification across multiple replicates $[31,32]$. Therefore, SWATH-MS might identify and quantify a higher number of proteins expressed simultaneously in $O$. moubata male and female saliva than LC-MS/MS, which in turn allows for comparing protein expression levels between both sexes.

Accordingly, we first assessed the performance and reproducibility of both methods in the identification of the 0 . moubata salivary proteome by comparing the results obtained by LC-MS/MS and SWATH-MS for the three replicate samples of each sex.

Regarding performance, LC-MS/MS analysis of the female samples resulted in the identification of 64 salivary proteins, while SWATH-MS of these same samples identified up to 165 salivary proteins (Table 2, Additional file 3: Table S2). Up to 
40 of these proteins were identified by both methods, 24 exclusively by LC-MS/MS and 125 exclusively by SWATH (Fig. 3A). In male saliva, 195 and 165 proteins were identified by LC-MS/MS and SWATH-MS respectively (Table 2, Additional file 3: Table S2). Up to 136 male proteins were identified by both methods, 59 solely by LC-MS/MS and 29 solely by SWATH-MS (Fig. 3A).

With a $62 \%$ increase in the number of proteins identified, our data suggest that in the context of the female saliva, SWATHMS is superior to DDA mode. However, in the male saliva DDA identified $15 \%$ more proteins than SWATH-MS. These data indicate that the benefit of SWATH over DDA MS, in the number of identified proteins, is unique for saliva of females and supports the notion that the performance of these techniques may be dependent on the fluid or the tissue analysed, as has been recently observed [32].

To assess the reproducibility in protein identification of both methods, we compared the data from the three biological replicates of female (F1, F2, F3) and male (M1, M2, M3) saliva. Fig. 3B shows that the reproducibility of LC-MS/MS was $27.3 \%$ and $36.6 \%$ in female and male saliva, respectively. On the other hand, the SWATH-MS reproducibility reached almost $100 \%$ (97-99\%) in both sexes (Fig. 3C). Therefore, SWATH-MS outperformed DDA in the reproducibility of proteins identified across all three technical replicate analyses, and these results are in good agreement with previous reports [31].

Additional file 3: Table S2 shows the global results from both MS methods, which jointly identified 299 salivary proteins using the sialotranscriptome of $O$. moubata females as a reference database [19].

\section{Quantification of the proteins identified in the female and male saliva by SWATH-MS}

As already noted, SWATH-MS is a type of DIA method of analysis used to evaluate quantitatively complex samples with high reproducibility [33].

Using this technique, we have identified and quantified 165 proteins in the saliva of both female and male ticks, which were later classified in 21 groups and families (Table 2, Additional file 4: Table S3). Not unexpectedly, these groups/families coincide with the groups/families more abundantly represented in the 0 . moubata sialotranscriptome [19]. The groups with the highest numbers of proteins were proteins involved in metabolic processes $(n=30)$ and protein modification $(n=12)$, proteases $(n=19)$, lipocalins $(n=11)$, antioxidants $(n=10)$, regulation $(n=10)$, and unknown function $(n=24)$.

Fig. 4 represents the expression levels of the protein groups/families in both sexes, calculated as the mean spectral signal peak area for female and male saliva (Additional file 4: Table S3). The 24 proteins with unknown function have been excluded from the pie charts, and the groups containing 5 or fewer proteins (proteins involved in metabolism, signal transduction, protein synthesis, extracellular matrix, proteasome machinery and transporters) have been merged in one group named "other".

Female saliva is predominantly composed of lipocalins as this group of proteins constitutes $95 \%$ of the saliva protein mass (Fig. 4A). The group includes 11 lipocalins, being moubatin (Q04669) and the so-named salivary lipocalin TSGP1 (F6K8G8) the most abundant as they respectively account for $40.39 \%$ and $55.33 \%$ of the total protein mass of this group (Additional file 4: Table S3).

Lipocalins are a large multigene protein family having dual functions as histamine and serotonin scavengers and as modulators of vertebrate inflammation and immunity [15]. Moubatin belongs to a lipocalin clade that includes proteins that inhibit platelet and neutrophil aggregation by scavenging of thromboxane A2 (TXA2) and proteins that inhibit complement activation by sequestering the C5 component [34]. TSGP1 belongs to the serotonin and histamine-binding

Page 9/24 
group of the soft tick lipocalins [35]. The current results confirm the previous report by Oleaga et al. [20] regarding the great abundance and numerous isoforms of TSGP1 discovered in the proteome of the salivary glands of 0 . moubata and support the notion that in 0 . moubata TSGP1 would be the main scavenger of histamine and serotonin. These proinflammatory biogenic amines accumulate at the tick-feeding site and need to be efficiently removed for the tick to successfully feed [33]. Regardless of its function, TSGP1 is highly immunogenic and strongly recognised by the serum from pigs bitten by 0 . moubata, which has made it a useful tool for serological diagnosis of parasitism by 0 . moubata [36]. In fact, a recombinant form of TSGP1 has been already used in several seroepidemiological studies of pig exposure to this tick in Madagascar, Mozambique and Nigeria [37-39].

The remaining non-lipocalin proteins represent only $5 \%$ of the total protein content of female saliva. Among them, proteases, protease inhibitors, antioxidants, and proteins involved in the metabolism of carbohydrates and lipids are the following more abundant groups representing between 0.82 and $0.42 \%$ of saliva protein content (Fig. $4 \mathrm{~A}$ ). In these groups, the more abundant proteins were a carboxipeptidase (B7QF76), a metalloprotease (Q09JT3), SCO-spondin-like (XP_021004313), enolase (D4P967), aldehyde dehydrogenase (B7QAL5), catalase (A0A2U8T6B2) and phospholipase A2 (M9W8K4) (Additional file 4: Table S3).

For several of these proteins, classified as housekeeping proteins, it is well established that they can also play important extracellular functions at the host-parasite interface, helping ticks to feed $[40,41]$. For instance, in 0 . moubata, salivary enolase acts as a pro-fibrinolytic plasminogen activator receptor [40] and salivary secreted phospholipase A2 plays as an antagonist ligand of host P-selectin preventing P-selectin mediated endothelial activation [43].

In quantitative terms, the proteome of male saliva is remarkably different from that of female saliva (Fig. 4B). In male saliva, lipocalins are also the most abundant proteins -though they only account for $27.12 \%$ of the saliva protein contentand TSGP1 (F6K8G8) is also the most abundant individual lipocalin accounting the $60 \%$ of the protein content of this group (Additional file 4: Table S3). The following more abundant groups were protease inhibitors (17.55\%) and the proteins involved in carbohydrate metabolism (15.71\%) (Fig. 3B), with serpin-2 (Q06B74) (52.27\%) and enolase (D4P967) $(55.72 \%)$ being their most abundant individual components, respectively.

Serpin 2 is a well-characterised serine protease inhibitor that inhibits trypsin and thrombin, and interferes with platelet aggregation and blood clotting [44,45]. This activity and the above-referred pro-fibrinolytic activity of enolase [42] would collaborate in maintaining host blood fluidity helping tick to feed.

Among the 165 proteins quantified by SWATH-MS in the saliva from males and females, 53 were differentially expressed $(p<0.05)$ between the sexes (Table 3); 13 proteins were over-expressed in females and 40 were overexpressed in males. The signal peak areas of the differentially expressed proteins in each of the samples analysed were shown using a heat map after z-score normalisation, using Euclidean distances. The hit map shows two main clusters comprising the F1-F3 samples and M1-M3 samples, which correspond to the saliva of females and males respectively (Additional file 5: Fig. S2).

Fig. 5 represents the top 10 proteins that are differentially $(p<0.05)$ overexpressed in the saliva of female or male ticks. As expected according to the above-reported results, the top 10 overexpressed proteins in females were 5 lipocalins, including moubatin and TSGP1, phospholipase A2, apyrase, a metalloprotease, a salivary secreted basic tail protein and a salivary basic tailless protein (Table 3). Apyrase has been identified in the saliva of most hematophagous vectors including soft and hard ticks. It is an enzyme that hydrolyses ATP and ADP to AMP and prevents platelet and neutrophil aggregation and thrombus formation, facilitating blood feeding $[46,47]$. A recombinant form of the salivary apyrase of 0 . moubata induced protective, strong humoral responses in animal vaccine trials that reduced tick feeding and survival [46].

In O. moubata, as in other ixodid and argasid tick species, metalloproteases are one of the enzyme classes most abundantly represented in the saliva $[14,19,48,49]$. In this study, LC-MS/MS and SWATH-MS identified 30 proteases, 16 of 
them metalloproteases and 5 differentially expressed $(p<0.05)$ between females and males $($ Table 3$)$.

Concerning basic tail and tailless proteins, their finding among the overexpressed proteins is not unexpected, as they are protein families abundantly found in the sialotranscriptomes of ixodid and argasid ticks, which suggest that they would play important and specific roles at the tick-host feeding interface $[14,19,48,49]$.

On the other hand, the top 10 proteins overexpressed in male saliva were two superoxide dismutases, two metabolic enzymes (adenosine amidase, hydroxypyruvate reductase), two proteins involved in immune mechanisms (gammainterferon inducible lysosomal thiol reductase, spätzle alternatively spliced isoform), three proteins with unknown function, and ixodidin (Table 3 and Fig. 5). This last protein is an inhibitor of serine proteinases that shows antimicrobial activity [50].

As a whole, these results show that at least 165 out of 299 of the salivary proteins identified in the current study are shared by both sexes, which significantly reduces the range of qualitative differences between male and female saliva observed in previous works, where only $5.2 \%$ of the identified proteins were found in both sexes [21]. However, these results keep showing remarkable differences in the ratios of salivary proteins that males and females secrete in their saliva, which raises the question of the biological significance of these differences. It could be speculated that it may be related to the post-feeding blood processing or attraction and mating [51], but neither our current results nor a revision of the literature offered evidence to support or rule out such a notion and shed light on this matter.

\section{Conclusions}

Previous studies on the salivary transcriptome of 0 . moubata adults were handicapped by the hyper-abundance of lipocalins, especially in female saliva, that impeded the identification of the less abundant proteins. Equalisation of saliva samples increased protein identification but precluded quantification of its protein components [28, 21].

To overcome these hindrances, herein we have analysed the proteome of the saliva of 0 . moubata males and females via two mass spectrometry techniques, conventional LC-MS/MS and quantitative label-free SWATH-MS, and have implemented proteomics informed by transcriptomics (PIT) analysis using the recently obtained sialotranscriptome of $O$. moubata females as a reference database for protein identification [19].

The SWATH-MS proved superior to LC-MS/MS in the study of female saliva since it increased by $60 \%$ the number of identified proteins, enhanced the reproducibility of the results and provided a quantitative image of the saliva components. Additionally, the PIT analysis demonstrated its usefulness for proteomics studies of O. moubata, a non-model organism for which there are no genomic sequences available. PIT is being increasingly and successfully implemented in proteomics studies of tick saliva fuelled by the increasing number of tick sialotranscriptomes available resulting from the progressively more frequent application of NGS techniques to tick salivary glands [16, 30].

As a whole, we have identified 299 non-redundant proteins in the 0 . moubata saliva and quantified the expression of 165 of them in both male and female saliva, among which 13 were significantly overexpressed in females and 40 in males. These results evidence important quantitative differences between sexes in the saliva proteome and confirm in part the results obtained in earlier works using different methodological approaches.

These findings expand our knowledge of the 0 . moubata sialome, particularly of female ticks, by increasing the identification of novel salivary proteins and functions at the tick-host feeding interface.

The integration of this new knowledge together with the information from the 0 . moubata sialotranscriptome will allow a more rational selection of the salivary candidates as antigen targets for tick vaccine development and testing in animal immunisation tests. For example, hyperabundant proteins, such as lipocalins, should not be considered as vaccine targets 
because their massive presence in saliva would most likely preclude their complete neutralisation by the vaccine-induced antibodies.

Finally, we believe that testing multiantigenic vaccine formulations that include protective intestinal and salivary antigens should be encouraged since these formulations will target different biological processes and may provide synergic protective effects leading to more effective vaccines for the control of the 0 . moubata infestations and pathogen transmission.

\section{Abbreviations}

$\mathrm{ABC}$

Ammonium bicarbonate; AM:Iodoacetamide; DDA:Data-dependent acquisition; DIA:Data-independent acquisition; FDR:False discovery rate; DTT:Dithiothreitol; GO:Gene Ontology; LC-MS/MS:Liquid chromatography-tandem mass spectrometry; SWATH-MS:Sequential window acquisition of all theoretical fragment ion spectra mass spectrometry; TFA:Trifluoroacetic acid.

\section{Declarations}

\section{Availability of data and materials}

The mass spectrometry proteomics data have been deposited to the ProteomeXchange Consortium via the PRIDE [52] partner repository with the dataset identifiers PXD025657, PXD025658, PXD025660, PXD025680.

\section{Ethics approval}

Animal experimentation in this study was performed according to the regulations established by the Ethical and Animal Welfare Committee of the IRNASA, CSIC, Spain, and the corresponding EU Law (Directive 2010/63/EU).

\section{Competing Interests}

The authors declare that they have no competing interests.

\section{Funding}

This research was funded by project RTI2018-098297-B-I00, granted by the Spanish Ministry of Science, Innovation and Universities.

\section{Author contributions}

AO and RPS conceived and designed the study, interpreted the data and drafted the manuscript. ACM contributed to construction of tables and figures. MLV performed the proteomic analyses and provided critical review and revisions. All authors read and approved the final manuscript.

\section{Acknowledgements}

The authors are grateful to Rocío Vizcaíno Marín and María González Sánchez from the Instituto de Recursos Naturales y Agrobiología de Salamanca (IRNASA, CSIC) (Spain) for their skilful technical assistance. We acknowledge support of the publication fee by the CSIC Open Access Publication Support Initiative through its Unit of Information Resources for Research (URICl). 
1. Jongejan F, Uilenberg G. The global importance of ticks. Parasitology. 2004;129 Suppl:S3-14.

2. Rochlin I, Toledo A. Emerging tick-borne pathogens of public health importance: a mini-review. J Med Microbiol. 2020;69(6):781-791.

3. Vial L. Biological and ecological characteristics of soft ticks (Ixodida: Argasidae) and their impact for predicting tick and associated disease distribution. Parasite. 2009;16(3):191-202.

4. Cutler SJ. Relapsing fever-a forgotten disease revealed. J Appl Microbiol. 2010;108(4):1115-22.

5. Talagrand-Reboul E, Boyer PH, Bergström S, Vial L, Boulanger N. Relapsing Fevers: Neglected Tick-Borne Diseases. Front Cell Infect Microbiol. 2018;8:98.

6. Penrith ML, Vosloo W, Jori F, Bastos AD. African swine fever virus eradication in Africa. Virus Res. 2013;173(1):228-46.

7. Penrith ML, Bastos AD, Etter EMC, Beltrán-Alcrudo D. Epidemiology of African swine fever in Africa today: Sylvatic cycle versus socio-economic imperatives. Transbound Emerg Dis. 2019;66(2):672-686.

8. Guerrero FD, Miller RJ, Pérez de León AA. Cattle tick vaccines: many candidate antigens, but will a commercially viable product emerge? Int J Parasitol. 2012;42(5):421-7.

9. Pérez-Sánchez R, Oleaga A. Acaricidal activity of fluralaner against Ornithodoros moubata and Ornithodoros erraticus argasid ticks evaluated through in vitro feeding. Vet Parasitol. 2017;243:119-124.

10. Oleaga-Pérez A, Pérez-Sánchez R, Encinas-Grandes A. Distribution and biology of Ornithodoros erraticus in parts of Spain affected by African swine fever. Vet Rec. 1990;126(2):32-7. PMID: 2301109.

11. de la Fuente J. Controlling ticks and tick-borne diseases...looking forward. Ticks Tick Borne Dis. 2018;9(5):1354-1357.

12. Díaz-Martín V, Manzano-Román R, Obolo-Mvoulouga P, Oleaga A, Pérez-Sánchez R. Development of vaccines against Ornithodoros soft ticks: An update. Ticks Tick Borne Dis. 2015;6(3):211-20.

13. Chmelař J, Kotál J, Karim S, Kopacek P, Francischetti IMB, Pedra JHF, Kotsyfakis M. Sialomes and Mialomes: A Systems-Biology View of Tick Tissues and Tick-Host Interactions. Trends Parasitol. 2016;32(3):242-254.

14. Mans BJ. Quantitative Visions of Reality at the Tick-Host Interface: Biochemistry, Genomics, Proteomics, and Transcriptomics as Measures of Complete Inventories of the Tick Sialoverse. Front Cell Infect Microbiol. 2020;10:574405.

15. Martins LA, Bensaoud C, Kotál J, Chmelař J, Kotsyfakis M. Tick salivary gland transcriptomics and proteomics. Parasite Immunol. 2020:e12807

16. Oleaga A, Obolo-Mvoulouga P, Manzano-Román R, Pérez-Sánchez R. A proteomic insight into the midgut proteome of Ornithodoros moubata females reveals novel information on blood digestion in argasid ticks. Parasit Vectors. 2017;10(1):366.

17. Oleaga A, Obolo-Mvoulouga P, Manzano-Román R, Pérez-Sánchez R. Functional annotation and analysis of the Ornithodoros moubata midgut genes differentially expressed after blood feeding. Ticks Tick Borne Dis. 2017b;8(5):693-708.

18. Obolo-Mvoulouga P, Oleaga A, Manzano-Román R, Pérez-Sánchez R. Evaluation of the protective efficacy of Ornithodoros moubata midgut membrane antigens selected using omics and in silico prediction algorithms. Ticks Tick Borne Dis. 2018;9(5):1158-1172.

19. Oleaga A, Soriano B, Llorens C, Pérez-Sánchez R. Sialotranscriptomics of the argasid tick Ornithodoros moubata along the trophogonic cycle. PLoS Negl Trop Dis. 2021;15(2):e0009105.

20. Oleaga A, Escudero-Población A, Camafeita E, Pérez-Sánchez R. A proteomic approach to the identification of salivary proteins from the argasid ticks Ornithodoros moubata and Ornithodoros erraticus. Insect Biochem Mol Biol. 2007;37(11):1149-59.

21. Díaz-Martín V, Manzano-Román R, Valero L, Oleaga A, Encinas-Grandes A, Pérez-Sánchez R. An insight into the proteome of the saliva of the argasid tick Ornithodoros moubata reveals important differences in saliva protein

Page 13/24 
composition between the sexes. J Proteomics. 2013;80:216-35.

22. Keidel, E.M., Ribitsch, D., Lottspeich, F., 2010. Equalizer technology-Equal rights for disparate beads. Proteomics 10, 2089-2098.

23. Ludwig C, Gillet L, Rosenberger G, Amon S, Collins BC, Aebersold R. Data-independent acquisition-based SWATH-MS for quantitative proteomics: a tutorial. Mol Syst Biol. 2018;14(8):e8126.

24. Baranda JA, Pérez-Sánchez R, Oleaga-Pérez A, Encinas-Grandes A. Antigens of interest for the diagnosis of parasitism in pigs by Ornithodoros erraticus and Ornithodoros moubata. J Parasitol. 1997;83(5):831-8.

25. Shilov IV, Seymour SL, Patel AA, Loboda A, Tang WH, Keating SP, Hunter CL, Nuwaysir LM, Schaeffer DA. The Paragon Algorithm, a next generation search engine that uses sequence temperature values and feature probabilities to identify peptides from tandem mass spectra. Mol Cell Proteomics. 2007;6(9):1638-55.

26. Kim TK, Tirloni L, Pinto AFM, Diedrich JK, Moresco JJ, Yates JR 3rd, da Silva Vaz I Jr, Mulenga A. Time-resolved proteomic profile of Amblyomma americanum tick saliva during feeding. PLoS Negl Trop Dis. 2020;14(2):e0007758.

27. Schubert OT, Gillet LC, Collins BC, Navarro P, Rosenberger G, Wolski WE, Lam H, Amodei D, Mallick P, MacLean B, Aebersold R. Building high-quality assay libraries for targeted analysis of SWATH MS data. Nat Protoc. 2015;10(3):426-41

28. Pérez-Sánchez R, Oleaga-Pérez A, Siles-Lucas M, Díaz-Martín V, De La Torre E, Hernández-González A, ManzanoRomán R. Aplicación de ecualizadores de proteínas para la identificación de antígenos minoritarios de Ornithodoros moubata. Proteómica 2010; 5:143-145.

29. Tan AW, Francischetti IM, Slovak M, Kini RM, Ribeiro JM. Sexual differences in the sialomes of the zebra tick, Rhipicephalus pulchellus. J Proteomics. 2015;117:120-44

30. Bensaoud C, Aounallah H, Sciani JM, Faria F, Chudzinski-Tavassi AM, Bouattour A, M'ghirbi Y. Proteomic informed by transcriptomic for salivary glands components of the camel tick Hyalomma dromedarii. BMC Genomics. 2019;20(1):675.

31. Collins BC, Hunter CL, Liu Y, Schilling B, Rosenberger G, Bader SL, Chan DW, Gibson BW, Gingras AC, Held JM, Hirayama-Kurogi M, Hou G, Krisp C, Larsen B, Lin L, Liu S, Molloy MP, Moritz RL, Ohtsuki S, Schlapbach R, Selevsek N, Thomas SN, Tzeng SC, Zhang H, Aebersold R. Multi-laboratory assessment of reproducibility, qualitative and quantitative performance of SWATH-mass spectrometry. Nat Commun. 2017;8(1):291.

32. Krasny L, Bland P, Kogata N, Wai P, Howard BA, Natrajan RC, Huang PH. SWATH mass spectrometry as a tool for quantitative profiling of the matrisome. J Proteomics. 2018;189:11-22.

33. Chapman JD, Goodlett DR, Masselon CD. Multiplexed and data-independent tandem mass spectrometry for global proteome profiling. Mass Spectrom Rev. 2014;33(6):452-70.

34. Mans BJ, Ribeiro JM. Function, mechanism and evolution of the moubatin-clade of soft tick lipocalins. Insect Biochem Mol Biol. 2008;38(9):841-852.

35. Mans BJ, Ribeiro JM, Andersen JF. Structure, function, and evolution of biogenic amine-binding proteins in soft ticks. J Biol Chem. 2008;283(27):18721-33.

36. Díaz-Martín V, Manzano-Román R, Siles-Lucas M, Oleaga A, Pérez-Sánchez R. Cloning, characterization and diagnostic performance of the salivary lipocalin protein TSGP1 from Ornithodoros moubata. Vet Parasitol. 2011;178(1-2):163-72.

37. Ravaomanana J, Jori F, Vial L, Pérez-Sánchez R, Blanco E, Michaud V, Roger F. Assessment of interactions between African swine fever virus, bushpigs (Potamochoerus larvatus), Ornithodoros ticks and domestic pigs in north-western Madagascar. Transbound Emerg Dis. 2011;58(3):247-54.

38. Quembo CJ, Jori F, Heath L, Pérez-Sánchez R, Vosloo W. Investigation into the Epidemiology of African Swine Fever Virus at the Wildlife - Domestic Interface of the Gorongosa National Park, Central Mozambique. Transbound Emerg Dis. 2016;63(4):443-51. 
39. Luka P, Mwiine FN, Yakubu B, Erume J, Pérez-Sánchez R, Unger H, Shamaki D. African swine fever virus transmission cycle in Nigeria: Assessment of domestic pig-soft tick contact through detection of antibodies against Ornithodoros moubata salivary antigen TSGP1. Veterinary Sciences: Research and Reviews. 2017 3(1): 6-12.

40. Francischetti IM, Sa-Nunes A, Mans BJ, Santos IM, Ribeiro JM. The role of saliva in tick feeding. Front Biosci (Landmark Ed). 2009;14:2051-88.

41. Cabezas-Cruz A, Alberdi P, Valdés JJ, Villar M, de la Fuente J. Anaplasma phagocytophilum Infection Subverts Carbohydrate Metabolic Pathways in the Tick Vector, Ixodes scapularis. Front Cell Infect Microbiol. 2017 Feb 7;7:23.

42. Díaz-Martín V, Manzano-Román R, Oleaga A, Encinas-Grandes A, Pérez-Sánchez R. Cloning and characterization of a plasminogen-binding enolase from the saliva of the argasid tick Ornithodoros moubata. Vet Parasitol. 2013;191(34):301-14.

43. Manzano-Román R, Díaz-Martín V, González-González M, Matarraz S, Álvarez-Prado AF, LaBaer J, Orfao A, PérezSánchez R, Fuentes M. Self-assembled protein arrays from an Ornithodoros moubata salivary gland expression library. J Proteome Res. 2012;11(12):5972-82.

44. Chmelar J, Oliveira CJ, Rezacova P, Francischetti IM, Kovarova Z, Pejler G, Kopacek P, Ribeiro JM, Mares M, Kopecky J, Kotsyfakis M. A tick salivary protein targets cathepsin $\mathrm{G}$ and chymase and inhibits host inflammation and platelet aggregation. Blood. 2011;117(2):736-44.

45. Ibelli AM, Kim TK, Hill CC, Lewis LA, Bakshi M, Miller S, Porter L, Mulenga A. A blood meal-induced Ixodes scapularis tick saliva serpin inhibits trypsin and thrombin, and interferes with platelet aggregation and blood clotting. Int $J$ Parasitol. 2014;44(6):369-79.

46. Díaz-Martín V, Manzano-Román R, Oleaga A, Pérez-Sánchez R. New salivary anti-haemostatics containing protective epitopes from Ornithodoros moubata ticks: Assessment of their individual and combined vaccine efficacy. Vet Parasitol. 2015;212(3-4):336-49.

47. Masoud HMM, Helmy MS, Darwish DA, Abdel-Monsef MM, Ibrahim MA. Apyrase with anti-platelet aggregation activity from the nymph of the camel tick Hyalomma dromedarii. Exp Appl Acarol. 2020;80:349-61.

48. Araujo RN, Silva NCS, Mendes-Sousa A, Paim R, Costa GCA, Dias LR, Oliveira K, Sant'Anna MRV, Gontijo NF, Pereira MH, Pessoa GD, Valenzuela JG, Koerich LB, Oliveira F. RNA-seq analysis of the salivary glands and midgut of the Argasid tick Ornithodoros rostratus. Sci Rep. 2019;9(1):6764.

49. Pérez-Sánchez R, Carnero-Morán Á, Soriano B, Llorens C, Oleaga A. RNA-seq analysis and gene expression dynamics in the salivary glands of the argasid tick Ornithodoros erraticus along the trophogonic cycle. Parasit Vectors. 2021;14(1):170.

50. Fogaça AC, Almeida IC, Eberlin MN, Tanaka AS, Bulet P, Daffre S. Ixodidin, a novel antimicrobial peptide from the hemocytes of the cattle tick Boophilus microplus with inhibitory activity against serine proteinases. Peptides. 2006;27(4):667-74.

51. Horigane $M$, Shinoda $T$, Honda $H$, Taylor $D$. Characterization of a vitellogenin gene reveals two phase regulation of vitellogenesis by engorgement and mating in the soft tick Ornithodoros moubata (Acari: Argasidae). Insect Mol Biol. 2010;19(4):501-15.

52. Perez-Riverol Y, Csordas A, Bai J, Bernal-Llinares M, Hewapathirana S, Kundu DJ, Inuganti A, Griss J, Mayer G, Eisenacher M, Pérez E, Uszkoreit J, Pfeuffer J, Sachsenberg T, Yilmaz S, Tiwary S, Cox J, Audain E, Walzer M, Jarnuczak AF, Ternent T, Brazma A, Vizcaíno JA. The PRIDE database and related tools and resources in 2019: improving support for quantification data. Nucleic Acids Res. 2019;47(D1):D442-D450.

\section{Tables}


Table 1

Number of salivary proteins in the spectral library. More details can be found in Additional file 3:

Table 2.

\begin{tabular}{|ll|}
\hline Classification & Number of proteins \\
\hline antioxidant/ detoxification & 20 \\
\hline cytoskeletal & 14 \\
\hline extracellular matrix & 5 \\
\hline glycine rich & 8 \\
\hline heme/ iron binding & 2 \\
\hline immune related/defense & 8 \\
\hline lipocalins & 15 \\
\hline metabolism, amino acids & 2 \\
\hline metabolism, carbohydrate & 13 \\
\hline metabolism, energy & 14 \\
\hline metabolism, lipids & 11 \\
\hline metabolism, nucleic acids & 8 \\
\hline nuclear regulation & 7 \\
\hline protease & 28 \\
\hline protease inhibitor & 17 \\
\hline proteasome machinery & 6 \\
\hline protein modification & 14 \\
\hline protein synthesis & 1 \\
\hline regulation & 15 \\
\hline signal transduction & 6 \\
\hline transporter/ receptors & 8 \\
\hline transposable element & 1 \\
\hline unknown function & 36 \\
\hline ToTAL & 259 \\
\hline
\end{tabular}


Table 2

Number of identified proteins in saliva from female and male ticks by LC-MS/MS and SWATH-MS. More details can be found in Additional file 3: Table 2.

\begin{tabular}{|llll|}
\hline Classification & \multicolumn{2}{l}{ LC-MS/MS } & SWATH-MS \\
\cline { 2 - 3 } & male & female & (male and females) \\
\hline antioxidant/ detoxification & 15 & 3 & 10 \\
\hline cytoskeletal & 10 & 1 & 9 \\
\hline extracellular matrix & 4 & 2 & 4 \\
\hline glycine rich & 9 & 1 & 8 \\
\hline heme/ iron binding & 0 & 2 & 1 \\
\hline immune related/defense & 8 & 2 & 6 \\
\hline lipocalins & 10 & 11 & 11 \\
\hline metabolism, amino acids & 1 & 1 & 1 \\
\hline metabolism, carbohydrates & 13 & 2 & 8 \\
\hline metabolism, energy & 13 & 1 & 12 \\
\hline metabolism, lipids & 10 & 2 & 6 \\
\hline metabolism, nucleic acids & 7 & 3 & 3 \\
\hline nuclear regulation & 0 & 0 & 1 \\
\hline protease & 18 & 12 & 19 \\
\hline protease inhibitor & 15 & 5 & 9 \\
\hline proteasome machinery & 3 & 0 & 2 \\
\hline protein modification & 14 & 1 & 12 \\
\hline protein synthesis & 1 & 0 & 1 \\
\hline regulation & 11 & 2 & 10 \\
\hline signal transduction & 6 & 0 & 3 \\
\hline transporter/ receptors & 7 & 1 & 5 \\
\hline unknown function & 195 & 64 & 165 \\
\hline TOTAL & & & 24 \\
\hline
\end{tabular}


Table 3

Proteins detected by SWATH-MS that are differentially expressed $(p<0.05)$ between female and male saliva. vs, versus.

\begin{tabular}{|c|c|c|c|c|c|c|}
\hline \multirow[t]{2}{*}{ Classification } & \multirow[t]{2}{*}{ Accession } & \multirow[t]{2}{*}{ Protein name } & \multicolumn{2}{|c|}{$\begin{array}{l}\text { Mean signal peak } \\
\text { area }(n=3)\end{array}$} & \multirow{2}{*}{$\begin{array}{l}\text { Fold } \\
\text { Change } \\
\text { (female } \\
\text { vs } \\
\text { male) }\end{array}$} & \multirow[t]{2}{*}{$\begin{array}{l}\text { p- } \\
\text { value }\end{array}$} \\
\hline & & & $\begin{array}{l}\text { female } \\
\left({ }^{*} 10^{4}\right)\end{array}$ & $\begin{array}{l}\text { male } \\
\left(* 10^{4}\right)\end{array}$ & & \\
\hline \multirow[t]{4}{*}{$\begin{array}{l}\text { antioxidant/ } \\
\text { detoxification }\end{array}$} & A0A2U8T6B2 & Catalase & 1.11 & 4.83 & 0.23 & $\begin{array}{l}3.87 \mathrm{E}- \\
02\end{array}$ \\
\hline & Q09JE3 & Superoxide dismutase [Cu-Zn] & 0.39 & 3.69 & 0.10 & $\begin{array}{l}1.26 \mathrm{E}- \\
03\end{array}$ \\
\hline & XP_026761353 & Superoxide dismutase [Cu-Zn] & 0.31 & 4.81 & 0.07 & $\begin{array}{l}2.86 \mathrm{E}- \\
02\end{array}$ \\
\hline & A6N9S1 & Thioredoxin peroxidase & 0.51 & 3.24 & 0.16 & $\begin{array}{l}7.70 \mathrm{E}- \\
04\end{array}$ \\
\hline \multirow[t]{3}{*}{ cytoskeletal } & A4UTU3 & Beta-actin & 5.51 & 50.56 & 0.11 & $\begin{array}{l}4.02 \mathrm{E}- \\
03\end{array}$ \\
\hline & XP_023220065 & Moesin/ezrin/radixin homolog 1 & 5.63 & 26.56 & 0.21 & $\begin{array}{l}7.10 \mathrm{E}- \\
04\end{array}$ \\
\hline & F0JA36 & Profilin & 3.05 & 10.49 & 0.29 & $\begin{array}{l}5.96 \mathrm{E}- \\
03\end{array}$ \\
\hline \multirow[t]{2}{*}{$\begin{array}{l}\text { extracellular } \\
\text { matrix }\end{array}$} & A0A3G1T1P7 & Mucin-like & 2.31 & 7.13 & 0.32 & $\begin{array}{l}6.90 \mathrm{E}- \\
03\end{array}$ \\
\hline & A0A3B0JRBO & Peritrophin-1 & 1.22 & 4.84 & 0.25 & $\begin{array}{l}1.67 \mathrm{E}- \\
02\end{array}$ \\
\hline glycine rich & XP_021703737 & $\begin{array}{l}\text { Glycine-rich cell wall structural } \\
\text { protein 1.8-like }\end{array}$ & 0.90 & 3.50 & 0.26 & $\begin{array}{l}9.07 \mathrm{E}- \\
03\end{array}$ \\
\hline \multirow[t]{3}{*}{$\begin{array}{l}\text { immune } \\
\text { related/defense }\end{array}$} & B7Q4R4 & $\begin{array}{l}\text { Double sized immunoglobulin G } \\
\text { binding protein A }\end{array}$ & 8.67 & 48.30 & 0.18 & $\begin{array}{l}4.34 \mathrm{E}- \\
02\end{array}$ \\
\hline & B7QIC3 & $\begin{array}{l}\text { Gamma-interferon inducible } \\
\text { lysosomal thiol reductase }\end{array}$ & 0.19 & 3.71 & 0.05 & $\begin{array}{l}1.27 \mathrm{E}- \\
03\end{array}$ \\
\hline & B7QFC1 & $\begin{array}{l}\text { Spatzle alternatively spliced isoform } \\
11.27\end{array}$ & 4.22 & 131.89 & 0.03 & $\begin{array}{l}2.34 \mathrm{E}- \\
02\end{array}$ \\
\hline \multirow[t]{5}{*}{ lipocalin } & Q04669 & Moubatin & $4,964.65$ & 48.28 & 102.84 & $\begin{array}{l}2.82 \mathrm{E}- \\
03\end{array}$ \\
\hline & B2D2A7 & Salivary lipocalin & 84.69 & 19.96 & 4.24 & $\begin{array}{l}2.38 \mathrm{E}- \\
02\end{array}$ \\
\hline & B2D2D9 & Salivary lipocalin & 3.98 & 0.90 & 4.40 & $\begin{array}{l}9.64 \mathrm{E}- \\
03\end{array}$ \\
\hline & F6K8G8 & Salivary lipocalin (TSGP1) & $6,801.11$ & 694.65 & 9.79 & $\begin{array}{l}1.80 \mathrm{E}- \\
04\end{array}$ \\
\hline & A6N9Y0 & Salivary secreted protein & 23.36 & 5.77 & 4.05 & $\begin{array}{l}6.85 \mathrm{E}- \\
03\end{array}$ \\
\hline \multirow[t]{2}{*}{ metabolism } & B7PV15 & $\begin{array}{l}\text { Glyoxylate/hydroxypyruvate } \\
\text { reductase }\end{array}$ & 2.58 & 55.15 & 0.05 & $\begin{array}{l}4.88 \mathrm{E}- \\
02\end{array}$ \\
\hline & B7PLL4 & Fructose-bisphosphatase & 1.04 & 2.04 & 0.51 & $\begin{array}{l}2.18 \mathrm{E}- \\
02\end{array}$ \\
\hline
\end{tabular}




\begin{tabular}{|c|c|c|c|c|c|c|}
\hline \multirow[t]{2}{*}{ Classification } & \multirow[t]{2}{*}{ Accession } & \multirow[t]{2}{*}{ Protein name } & \multicolumn{2}{|c|}{$\begin{array}{l}\text { Mean signal peak } \\
\text { area }(n=3)\end{array}$} & \multirow{2}{*}{$\begin{array}{l}\text { Fold } \\
\text { Change } \\
\text { (female } \\
\text { vs } \\
\text { male) }\end{array}$} & \multirow[t]{2}{*}{$\begin{array}{l}\mathrm{p}- \\
\text { value }\end{array}$} \\
\hline & & & $\begin{array}{l}\text { female } \\
\left({ }^{\star} 10^{4}\right)\end{array}$ & $\begin{array}{l}\text { male } \\
\left({ }^{*} 10^{4}\right)\end{array}$ & & \\
\hline & B7PFJ2 & Isocitrate dehydrogenase [NADP] & 0.18 & 1.47 & 0.12 & $\begin{array}{l}5.90 \mathrm{E} \\
04\end{array}$ \\
\hline & XP_013773334 & Lysosomal alpha-glucosidase-like & 8.50 & 12.39 & 0.69 & $\begin{array}{l}4.10 \mathrm{E} \\
02\end{array}$ \\
\hline & XP_023224832 & Acyl-CoA-binding protein-like & 0.20 & 1.33 & 0.15 & $\begin{array}{l}3.74 \mathrm{E} \\
03\end{array}$ \\
\hline & B7QMW0 & Fatty acid-binding protein FABP & 8.94 & 46.22 & 0.19 & $\begin{array}{l}3.48 \mathrm{E} \\
03\end{array}$ \\
\hline & M9W8K4 & Phospholipase A2 & 38.00 & 5.98 & 6.36 & $\begin{array}{l}3.39 \mathrm{E} \\
02\end{array}$ \\
\hline & B7PJJ3 & Adenosine deaminase, putative & 7.85 & 89.73 & 0.09 & $\begin{array}{l}1.57 \mathrm{E} \\
02\end{array}$ \\
\hline & M9WFX8 & Apyrase & 24.37 & 7.79 & 3.13 & $\begin{array}{l}2.96 \mathrm{E} \\
03\end{array}$ \\
\hline \multirow[t]{7}{*}{ protease } & E0AD92 & Angiotensin-converting enzyme & 8.46 & 44.25 & 0.19 & $\begin{array}{l}1.00 \mathrm{E} \\
03\end{array}$ \\
\hline & A0A087UKQ1 & Carboxypeptidase & 0.58 & 3.45 & 0.17 & $\begin{array}{l}7.00 \mathrm{E} \\
04\end{array}$ \\
\hline & B7QF76 & Carboxypeptidase & 33.37 & 38.82 & 0.86 & $\begin{array}{l}1.41 \mathrm{E} \\
02\end{array}$ \\
\hline & B7QBM2 & Dipeptidyl aminopeptidase III & 0.84 & 1.77 & 0.47 & $\begin{array}{l}2.69 \mathrm{E} \\
02\end{array}$ \\
\hline & A0A482VVE0 & Endothelin-converting enzyme 1 & 2.47 & 17.33 & 0.14 & $\begin{array}{l}7.80 \mathrm{E} \\
04\end{array}$ \\
\hline & Q09JT3 & Metalloprotease & 21.92 & 5.97 & 3.67 & $\begin{array}{l}3.23 \mathrm{E} \\
02\end{array}$ \\
\hline & Q1ZZW9 & Metalloproteinase & 3.20 & 1.12 & 2.85 & $\begin{array}{l}3.82 \mathrm{E} \\
02\end{array}$ \\
\hline $\begin{array}{l}\text { protease } \\
\text { inhibitor }\end{array}$ & B2D258 & Ixodidin & 0.95 & 14.56 & 0.06 & $\begin{array}{l}4.59 \mathrm{E} \\
02\end{array}$ \\
\hline \multirow[t]{5}{*}{$\begin{array}{l}\text { protein } \\
\text { modification }\end{array}$} & A0A1L5L8R3 & Heat shock protein $70-8235$ & 0.33 & 1.53 & 0.21 & $\begin{array}{l}2.05 \mathrm{E} \\
03\end{array}$ \\
\hline & XP_023224182 & Heat shock protein 83-like & 3.81 & 11.84 & 0.32 & $\begin{array}{l}7.58 \mathrm{E} \\
03\end{array}$ \\
\hline & B7PAR6 & Heat shock protein, putative & 9.47 & 22.96 & 0.41 & $\begin{array}{l}1.45 \mathrm{E} \\
02\end{array}$ \\
\hline & Q86G69 & Heat shock-related protein & 0.61 & 3.82 & 0.16 & $\begin{array}{l}3.61 \mathrm{E} \\
03\end{array}$ \\
\hline & A0A0A0N845 & Small heat shock protein I & 15.03 & 47.30 & 0.32 & $\begin{array}{l}3.04 \mathrm{E} \\
03\end{array}$ \\
\hline
\end{tabular}




\begin{tabular}{|c|c|c|c|c|c|c|}
\hline \multirow[t]{2}{*}{ Classification } & \multirow[t]{2}{*}{ Accession } & \multirow[t]{2}{*}{ Protein name } & \multicolumn{2}{|c|}{$\begin{array}{l}\text { Mean signal peak } \\
\text { area }(n=3)\end{array}$} & \multirow{2}{*}{$\begin{array}{l}\text { Fold } \\
\text { Change } \\
\text { (female } \\
\text { vs } \\
\text { male) }\end{array}$} & \multirow[t]{2}{*}{$\begin{array}{l}\mathrm{p}- \\
\text { value }\end{array}$} \\
\hline & & & $\begin{array}{l}\text { female } \\
\left(* 10^{4}\right)\end{array}$ & $\begin{array}{l}\text { male } \\
\left(* 10^{4}\right)\end{array}$ & & \\
\hline $\begin{array}{l}\text { protein } \\
\text { synthesis }\end{array}$ & B7Q349 & Elongation factor 1-alpha & 1.34 & 5.84 & 0.23 & $\begin{array}{l}1.70 \mathrm{E} \\
04\end{array}$ \\
\hline \multirow[t]{2}{*}{ regulation } & XP_013771971 & L-asparaginase-like isoform X1 & 0.11 & 0.78 & 0.14 & $\begin{array}{l}2.86 \mathrm{E} \\
02\end{array}$ \\
\hline & XP_023224526 & $\begin{array}{l}\text { Protein/nucleic acid deglycase DJ-1- } \\
\text { like }\end{array}$ & 0.84 & 4.39 & 0.19 & $\begin{array}{l}1.55 \mathrm{E} \\
02\end{array}$ \\
\hline $\begin{array}{l}\text { signal } \\
\text { transduction }\end{array}$ & A0A076FFP4 & Calmodulin & 0.51 & 2.68 & 0.19 & $\begin{array}{l}7.70 \mathrm{E} \\
05\end{array}$ \\
\hline $\begin{array}{l}\text { transporter/ } \\
\text { receptor }\end{array}$ & B7PIZ1 & Rab GDP dissociation inhibitor & 2.76 & 8.05 & 0.34 & $\begin{array}{l}1.85 \mathrm{E} \\
02\end{array}$ \\
\hline \multirow[t]{8}{*}{$\begin{array}{l}\text { unknown } \\
\text { function }\end{array}$} & XP_023235971 & $\begin{array}{l}\text { Ectonucleotide } \\
\text { pyrophosphatase/phosphodiesterase } \\
\text { family member } 1 \text {-like }\end{array}$ & 19.42 & 7.65 & 2.54 & $\begin{array}{l}9.09 \mathrm{E} \\
05\end{array}$ \\
\hline & F0J8E8 & Hypothetical secreted protein 1669 & 10.87 & 141.08 & 0.08 & $\begin{array}{l}2.03 \mathrm{E} \\
02\end{array}$ \\
\hline & A6N9P6 & Salivary basic tailless protein & 3.39 & 0.54 & 6.30 & $\begin{array}{l}3.91 \mathrm{E} \\
03\end{array}$ \\
\hline & B2D272 & Salivary secreted basic tail protein & 21.65 & 3.00 & 7.21 & $\begin{array}{l}8.54 \mathrm{E} \\
03\end{array}$ \\
\hline & A0A3B0JWSO & Uncharacterized protein & 0.55 & 2.25 & 0.24 & $\begin{array}{l}4.83 \mathrm{E} \\
02\end{array}$ \\
\hline & B7PLU7 & Uncharacterized protein & 0.34 & 46.32 & 0.01 & $\begin{array}{l}4.69 \mathrm{E} \\
02\end{array}$ \\
\hline & B7Q6K2 & Uncharacterized protein & 3.23 & 1.09 & 2.96 & $\begin{array}{l}7.50 \mathrm{E} \\
03\end{array}$ \\
\hline & B7QC55 & Uncharacterized protein & 14.66 & 587.39 & 0.02 & $\begin{array}{l}6.23 \mathrm{E} \\
05\end{array}$ \\
\hline
\end{tabular}

\section{Figures}




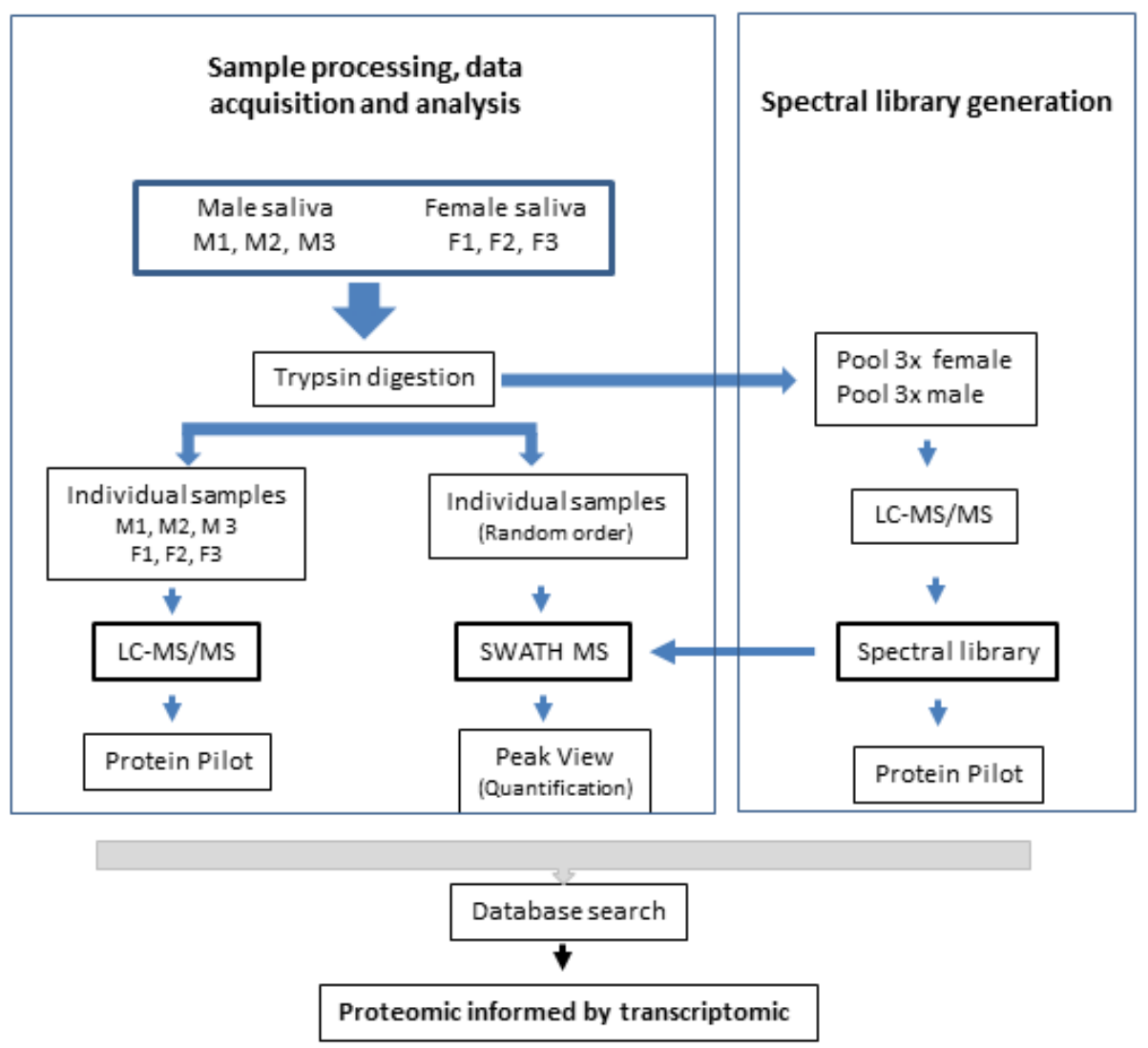

\section{Figure 1}

Schematic of experimental workflow employed in this study

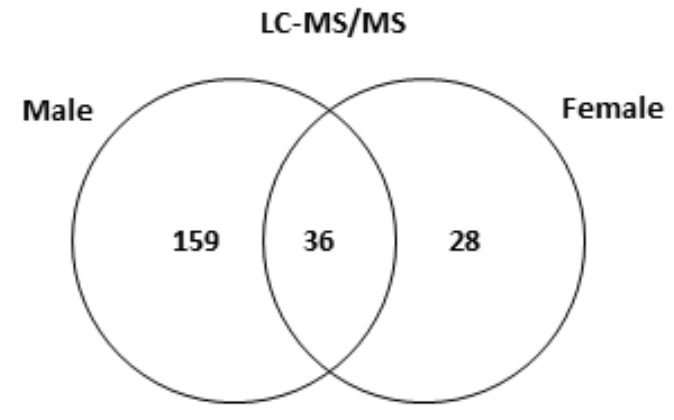

\section{Figure 2}

Venn diagram depicting number and overlap of non-redundant salivary proteins detected by LC-MS/MS. 
A

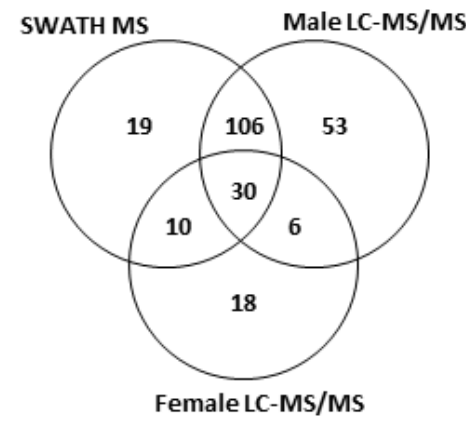

B

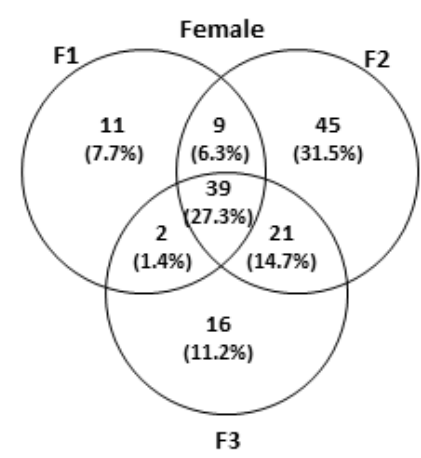

LC-MS/MS (DDA mode)

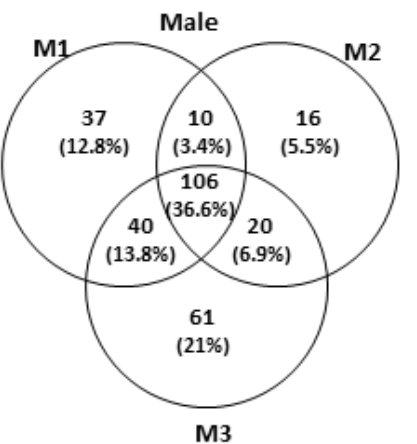

C

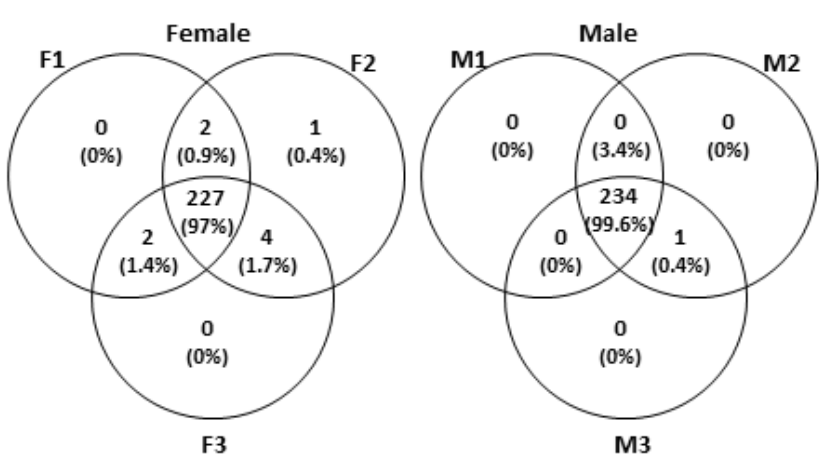

Figure 3

Comparative analysis of the performance of SWATH-MS and LC-MS/MS. A) Venn diagram depicting number and overlap of salivary proteins detected by LC-MS/MS and SWATH. B) and C) Venn diagrams depicting the number and overlap of unique proteins detected by LC-MS/MS and SWATH respectively across three biological replicates in female (F1, F2, F3) and male (M1, M2, M3) tick saliva. 
A

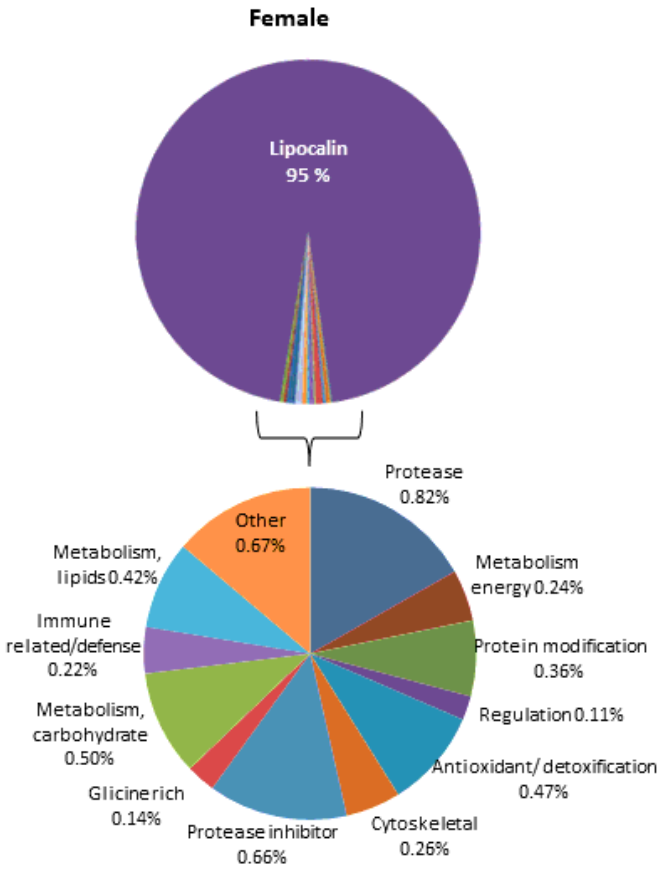

B

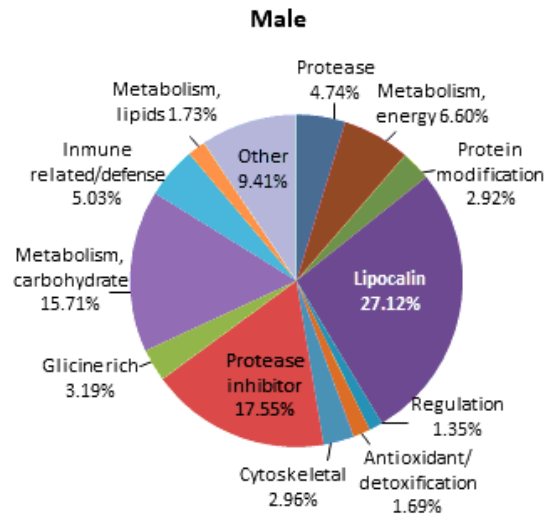

\section{Figure 4}

Expression level of the identified proteins classified by functional groups. The expression level was calculated as the mean spectral signal peak area in female (F1, F2, F3) (A) and male (M1, M2, M3) (B) samples. 


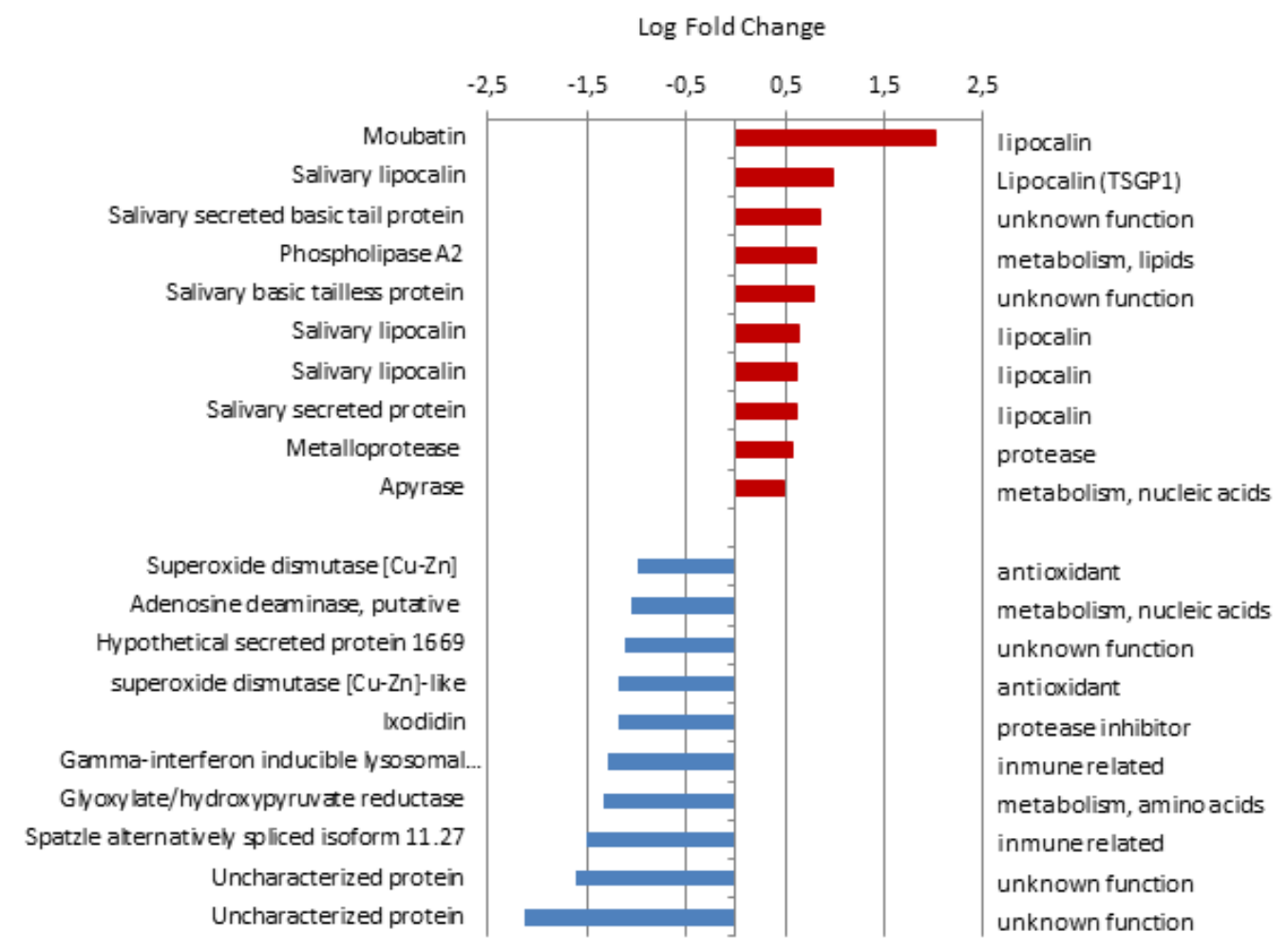

Figure 5

Top 10 proteins that are differentially $(\mathrm{p}<0.05)$ overexpressed in female saliva (red) or male saliva (blue).

\section{Supplementary Files}

This is a list of supplementary files associated with this preprint. Click to download.

- Additionalfile1Fig.S1.tif

- Additionalfile2TableS1.xlsx

- Additionalfile3Tables2.xlsx

- Additionalfile4TableS3.xlsx

- Additionalfile5Fig.S2.tif

- Graphicalabstract.tif 